Tarih Kültür ve Sanat Araştırmaları Dergisi

Revue des Recherches en Histoire Culture et Art

مجلة البحوث التاريخية و الثقافية والفنية
Vol. 7, No. 3, September 2018

Copyright (C) Karabuk University

http://kutaksam.karabuk.edu.tr

\title{
DOI: 10.7596/taksad.v7i3.1737
}

Citation: Myreeva, A. (2018). Folklore and Epic Traditions in Yakut Novels between Two Ages. Journal of History Culture and Art Research, 7(3), 460-468. doi:http://dx.doi.org/10.7596/taksad.v7i3.1737

\section{Folklore and Epic Traditions in Yakut Novels between Two Ages}

\section{Anastasiya Nikitichna Myreeva ${ }^{1}$}

\begin{abstract}
The study of present-day folklore and epic traditions remains an important topic and the evolution of epic prose genres in Yakut literature serves as an evidence to this. A complete turn to the folklore and epic traditions at the new stage of evolution is typical for the genre of historical and philosophical novel. A deeper indulgence into the historical plane and much more prominent manifestations of the moral and philosophical point of views predetermined the new steps in the development of traditional poetic features and olonkho. The focus on the psychological and mental structures of the traditional cultural consciousness predefined the turn to the main source of human memory: myths, legends and olonkho. Novels written by V.S. Yakovlev-Dalan and I.M. Gogolev are prominent examples of turning to the traditional poetic features in the new stage of Yakut literature development. Thus, in their novels, written in the new stage of Yakut literature, we can see features of mythological and folklore and olonkho traditions. Folklore and epic motifs are represented in several planes and on different text levels of the epic plot: in the point of view of the author, in the stylistic features, and in the portrayal of the characters personal traits. This article examines the role of folklore and epic traditions in the process of the modern historical and philosophical novel evolution; as well as to single out the folklore and mythological motifs by implementing historical and literary analysis, typological, conceptual and geocultural methods.
\end{abstract}

Keywords: Folklore and epic, Traditions, Olonkho, Mythological, Image, Motifs, Novel, Historical and biographical, Style, Text.

\footnotetext{
${ }^{1}$ Institute for Humanities Research and Indigenous Studies of the North RAS SB, Yakutsk, Russia. E-mail: anastmyreeva@yandex.ru
} 


\section{Introduction}

Folklore, epic and olonkho traditions played a key role in the emergence and development of Yakut literature genres. This topic retains its importance on the modern stage of literature development. This can be clearly seen in the evolution of the largest epic genre - the novel. In terms of the study methods in researching this topic, we base our findings on the research carried out by I.V. Pukhov, V.T. Petrov, K.D. Utkin, etc.

The traditional and poetic features manifest themselves in a literary text on several planes: in the plot and compositional structure; in the special stylistic features; in the expression of the point of view of the author; and in the moral and philosophical concept in general.

As V.T. Petrov noted "the boundaries of folklore influence on Yakut prose are large. Olonhko transitioned themselves from narrated stories, legends, fairytales and heroic epic to short stories and novelettes of authors along with the stylistic devices and expressive means of portraying humans and the plot and compositional devices enriched as a result of the authors' learning from the creative mastery of Russian classic writers; together, they form the basic creative resources of shaping the national style of Yakut prose" (Petrov, 1978, p.137).

I.V. Pukhov, a scholar who studied olonkho, singled out the heroic epic style features. They are: set formulas, a large variety of expressive means and hyperbole. The scholar pointed out the significance of nature descriptions in olonkho: "Nature is personified in olonkho. It is strongly connected with the unfolding events. The nature reacts to these events and take part in them" (Pukhov, 1980, pp.44-45). When characterizing the function of the main character in the olonkho, the scholar singled out the biographical basis of his life story description.

Another scholar, K.D. Utkin, focused his attention on the philosophical basics in olonkho; he viewed olonkho as a system of triangular interdependence of mythology, religion and pre-philosophy: "olonkho is a spiritual cosmos of the people of Sakha, its special kind of cosmic universe" (Utkin, 2006, p.176).

The indicated features of traditional epic literature have manifested themselves in their own special way in the evolution process of the epic prose genre.

\section{Methods}

The importance and novelty of the topic under the present study is predetermined by the fact that in the literature studies, there is no research devoted to a special overview of the role of folklore and epic traditions in the Yakut novels of the end of the $20^{\text {th }}$ and the beginning of the $21^{\text {st }}$ centuries.

The aim of the research is to study the role of folklore and epic traditions in the process of the modern historical and philosophical novel evolution; as well as to single out the folklore and mythological motifs which manifest themselves on different text levels of the folklore storyline.

The following research methods were used in the present study: historical and literary analysis, typological, conceptual and geocultural methods.

\section{The traditions of P. A. Oyunsky}

Initially, folklore features strongly recurred in prose of the 1920-1930s in the literatures of P.A. Oyunsky. Thus, in the poem titled The Red Shaman and referred to as an olonkho-toyuk as well as in the novelette titled Kudangsa the Great, the author naturally extended the olonkho traditions, which combines in itself "the mythology of the traditional shamanistic worldview" (P.A. Oyunsky). 
These literary works are filled with cosmogonic representations that the ancient Yakut people had about the universe, the human destiny, and the fate of the people. In literary works by P.A. Oyunsky, the categories of time and space are truly cosmic in their character; the human is depicted as the central figure of the universe.

Philosophical short stories and novelettes have played a significant role in the development of the prose genre in Yakut literature. These works of art are biographical. One of the most prominent literary works written by P.A. Oyunsky is the novelette legend titled Kudangsa the Great (1929); it is structured as an epic legend and this predetermined the importance of his poetics. In the olonkho tradition, special style features are justified by the fact that the story is told from the point of view of the author, a storyteller who is a representative of the traditional culture.

The main character faces an unfortunate fate: being incredibly will-powered, Kudangsa the Great sees his destiny in serving the people and rises against the forces of fate by claiming a person's right to live: "the wit and goals of the two-legged being will never cease to exist". In an attempt to save his people from a natural disaster, he sacrifices his most prized possession: his future and his children. A person, who is courageous enough to battle against the natural forces, dies: "His fault is that he was remarkably fearless, his biggest sin is that he had a lot of wit" (Oyunsky, 1995, p.65).

The language of the novelette is exceptionally expressive and rich in terms of the intonation patterns. It reflects the essence of the worldview of the people who created the song epic. The novelette is filled with expressive colloquial speech; it has a special rhythm and melody created by the use of repetitions of inversions and complex syntactic structures. At the same time, the author intentionally makes the language sound more archaic, which allowed recreating the cultural environment of the distant past.

In the olonkho-telling tradition, nature descriptions play an essentially important role in expressing the philosophical concept; individual cosmism of the worldview of the people is expressed in the unity of the person and nature. The central landscape image or the Mother Earth depicted virtuously in the language of olonkho is seen as such: "rimmed by an eight-colored bright rainbow and lit by the shining bright sun... precious land of the Sakha, though it sighs heavily, thrusting northern lights into the skies... though it breathes with freezing-cold wind, the native land gained limitless riches, everlasting future, it brought up and nurtured on itself the people of Sakha" (Oyunsky, 1995, p.65). Individual, epic rhythm of the storyline is created using repetitions and fixed poetic formulas.

Unlike this novelette, Nikolai Dorogunov, another novelette by P.A. Oyunsky, is set closer to the modern day life. The author once again identified this work of art as one belonging to the novelette legend. The fairytale style of this novelette plays a significant role; this is also connected with and based on the features of traditional olonkho epic.

The novelette is filled with insertions from other traditional poetry genres, such as toyuk and blessing or algys. This style is characterized by rich descriptions, repetitions of set constructions and the use of traditional epithets. Once again prose acquires a particular rhythm. The description of the joyous flourishing of nature in springtime sounds like a poem put in prose. This naturally transforms into an anthem of eternal love and joy of life. This literary work is about the philosophy of love as the greatest source of human happiness.

Long live Love,

There is no life without love!

The courage that P.A. Oyunsky displayed as a writer and a citizen in the times of the 1920-1930s, manifested itself in the fact that philosophical, moral and humanistic aspects of the people's poetic art, and olonkho in 
particular, should never lose its value. The rich capacity of cultural and historical, social and moral experience of the Sakha people, which was pondered upon and put into verse by P.A. Oyunsky, nowadays allows speaking of the author's creative reproduction of the cultural mentality of his own people - the people of Sakha.

Philosophical prose traditions of P.A. Oyunsky were continued by various writers in their creative writing during different time-periods in the history of Yakut literature. The creative writing of D.K. Sivtsev Suorun Omollon is a linking element between the humanistic traditions, the traditional character of Yakut classic literature and the modern-day period.

Humanistic features of a writer lie in the traditions of the native poetic art. He claimed that in the images and symbols of olonkho, eternal problems that the humanity had always pondered about ("problems of creativity, love and happiness of the children of the sun") are discussed and solved during the course of its history.

The traditions established by P.A. Oyunsky are based on the natural acquisition of traditional epic and were continued in different time-periods of history of the Yakut literature in the creative works of classic writers.

Traditional and poetic traditions underwent a unique evolutionary process: at the initial stage of the Yakut prose genres development there is a prominently active role of folklore; in the further stages of development, however, due to a number of reasons, this tendency is scarcely maintained.

Nevertheless, the tradition continues to exist in the epic prose form and attained a fresh and deeper content. Thus, in the following epic novels of the 1940-1950s: Spring time $(1942,1952)$ by N.E. MordinovAmma Achygyia and in Fate $(1947,1964)$ by N.G. Zolotaryov-Yakutskiy the folklore and epic tradition forms the basis of the philosophical concept of the world and humans in particular and the traditional lifestyle in general.

\section{Renewal of the traditional poetic features in the historical novel genre}

The literary process in the 1980-1990s is marked by a new interest in the traditional and poetic heritage, in olonkho, in particular and in epic legends and myths in general; this is largely defined by the growing rates of the people's national self-identification and the increasing level of interest towards the historical monuments of the people and to the moral roots.

A new historical outlook in the novel genre became evident in the Yakut literature in 1990s. A qualitative renewal of the epic traditions is a feature that makes prominent the creative writings by V. Yakovlev-Dalan, I. Gogolev, N. Luginov, E. Neimokhova, P. Oiuku, and others. A deeper insight into the historical aspect and the moral and philosophical views, predetermined the return to the traditional poetic forms of art, to olonkho in particular, but on a completely new level. The new form of national self-identity predefined the change towards the description of the ethnic and cultural wealth of a nation. The focus on the psychological and mental structures of traditional consciousness leads to an active reversal towards the main sources of national memory - myths, legends and olonkho. In just a twenty years time-period a whole range of historical novels was created: The deaf Viluy and Tygyn Darkhan by V. Dalan, The echoes of the past by N. Petrov, Manchaary by I. Gogolev, By the will of Genghis Khan by N. Luginov, The tract road by P. KharitonovOiuku, and others.

The epic novel Tygyn Darkhan (1993) by V. Dalan became the work of art which turned a new page in the history of Yakut literature. The text of the novel is based on the ethnographic and folklore materials. The novel by V. Dalan is marked by a genre syncretism; the philosophy of traditional life is represented as a unity of ethnographic, historical, biographical, social and domestic, moral and psychological aspects. 
The text of the epic storyline is based on traditional legends; it also contains olonkho poetics, a feature that predefined the special stylistic storytelling features. Using his creativity, the author reinterpreted the traditional legends and reminiscences from olonkho by looking at them through the prism of his personal perspective and by enriching it with the emotionality of a patriot and a humanist.

The encompassing philosophy of traditional life and the ethnographically precise depiction of the traditional way of life of the Sakha people are features that lay the foundation of the author's concept and determine the uniqueness of the historical novel with respect to its genre structure.

On the other hand, the textual basis of the author's point of view is characterized by an indepth lyrism. Depictions of native nature are filled with love similar to the one a son feels towards his mother; this often occurs in lyrical digression. Such is the depiction of nature awakening in spring in the Tuymaada valley.

In the olonkho tradition, the epic images of nature, "the geographical setting" of sacred places reproduce the unique geocultural atmosphere of the region. Thorough descriptions of landscapes is a special features of the olonkho poetics and it developed in the modern epic genre. Mythologism and animism are integral components of the epic storyline; they allow reproducing the relation to and the view towards the world as well as the religious worldviews of the people. Numerous mythological characters ignite the world of nature: the central images - the mistress of nature, Alakhchyn Khotun, the god of horse breeding - Zhegesey, the cruel bull of winter as well as the spirits of grass plants and trees.

The ordinary rhythm if nature's life in a novel lies in the logic of the novel storyline, adding up to the multiplane reproduction of cultural interrelations of the people of the north with the natural world. The main calendar holiday of the people of Sakha - Ysyakh - a holiday of harvest, is depicted in the mythological and poetic context. This holiday encompasses the labor and household, the cultural and religious view of the people. Ysyakh is shown as an anapheosis of peaceful life, a symbol of spiritual unity of the people, an anthem to native nature, and life itself.

L. N. Gumilyov once wrote that "ethnicities... are always connected with the natural surroundings owing to the active agricultural lifestyle. The latter aspect is visible in two trends: adaptation to the landscape and the adaptation of the landscape to the humans" (Gumilyov, 1989, p.58).

The geocultural world of the region is also unique. In its center, there is a mythical and poetic locus of the Tuymaada valley, the cradle of the people of Sakha, which attains and archetipical meaning, allowing to reproduce the unity of relations between time and space, by indicating all the following aspects - time, place, and uniqueness of the choronotope.

The style of narration is filled with intonation patterns typical for the traditional epic; it is picturesque, festive, filled with metaphors, similes, repetitions and syntactic parallelisms as well as with epic legends. The style of such novels is based on the revival of archaic forms of the Sakha language. This enhances the storyline with a deep philosophical meaning in the manifestation of eternal life values. In the novel, the ethnic sphere of traditional life is expressed through the following concepts: ysyakh, osuokhai, alaas, urasa (dwelling), etc.

Olonkho traditions reflect the biographical basis of the novel text. This basis of the story plot is predetermined by the author turning to the image of a historical figure and a leader of the Sakha people. The center of the epic structure of the novel is the tragic image of the main character of the traditional legends - Tygyn. Just like the main character of the story by P.A. Oyunsky, this character is caught up by the idea of serving the people; ever since his childhood, his only aim is to unite the Yakut tribes into one powerful II (world). In the description in the life journey of the main character, the author keeps in line with the logical character of legendary tales: Tygyn's tragedy lies in the fact that becoming certain in the lack of peaceful ways of solving the problems, he gradually and strongly convinces himself in the need to force the 
people to unite. A historian once wrote: "Tygyn is a prominent and dimensional character in the historical and ethnic memory of the Sakha people, and an important component of teh Sakha ethnic consciousness. This character encompasses the traditional representations and ideals about people, both positive and negative as well as spiritual values of the Medieval culture and symbols of an entire era" (Borisov, 1998, p.33).

It is impossible to reproduce national mentality in a written form without showing the interrelations of generations. Tygyn's father - Munnzhan Darkhan - bequeathed his son to complete the most important task: to assure peace and to prevent the native land from becoming deserted. The images of Tygyn's children are depicted in the folklore setting, mainly: his son, Keremes and daughter Tesan. These images are based on the testament of their ancestors, which implies the philosophy of life focused on love and kindness.

Despite the tragic fates of the main characters, in the context of optimistic olonkho concepts in the polyphony of the creative system of epic novels, this remains to be the most important aspect: the traditional ideal of a peaceful life, and in an eternal life conflict of war and peace, the priority is given to peace, poetry of human relations, based on love and consolidation.

In terms of its philosophical and aesthetic concept as well as structural and stylistic features, the novel by V. Dalan largely predetermined the perspectives of developing the modern genre of epic literature.

\section{Mythical and poetical novels by I. Gogolev}

In the Yakut prose of the 1990s, there is a tendency towards depicting unique or "new type of fictional motif of life depiction" which can be clearly seen in the following novels: The Black Crane (1977-1978), The Goddess of Mercy (1993), The Third Eye (1999), Manchaary (2001) by I. Gogolev. His novels tend to contain this new literary feature (Volkov, 1995, p.253).

The Yakut writer follows the trend of magic realism in the 20th century world literature, which saw such prominent writers as Jorge Amado, Garcia Markes, Gabriel Garcia Marquez, Chyngyz Aitmatov, and some others, all which developed types of conscious intellectual usage of mythology in prose style.

The problematic scope of novels by I. Gogolev is represented by intense moral and philosophical searches; the author is interested in the entire spectrum of worldview issues that the modern society is facing. In his prose, the author's role predetermines the emotional and lyrical character of the storyline. In the trilogy titled The Black Crane, comparing and contrasting the fates of the shaman and olonkhosut (olonkho teller), the author singles out the superior destiny of the traditional storyteller: he is destined to serve the forces of good, and to spread hope in the good in life by using the power of magic words. In the legend about Dzhyrylaan Udaganka (shaman girl), the heroine of the fills people's hearts with kindness and heals the afflicted by playing on the khomus and blessing by performing the algys ritual. A political dissident, whose last name is Staroverov, admits that the fairytales and legends as well as olonkho, helped him understand the soul of the Yakut people, their philosophy and moral commandments.

In the novel titled The Goddess of Mercy, the key role in expressing the philosophical concepts is given to myths and legends; being style-forming source, folklore poetry attains a new melody and becomes more natural. In this novel written in the best traditions of magic realism, several aspects - the real and the fantastic, the historical and the mythological coexist resulting in multiple interpretations and having complex philosophical implications.

In terms of the concept behind the story, this is a legend about people who have banished the goddess of mercy who appeared before them in an image of beautiful young woman. The tragedy in the story lies in 
the compassion towards people who willingly banished god from their souls and thus this led to the death of nature (the fate of the Viluy River).

The author is showing his concern that the desire to become prosperous can lead the human onto a path of treachery against the best ideals and to the loss of moral values; all these aspects form a contemporary problem which is portrayed by the author of the novel. The concluding idea of the novel is that only at the expense of hardships and trials humans can once again regain hope and the Goddess of Mercy will return to them.

The latest novel by I. Gogolev titled Manchaary is life story of a character of many myths and legends Vasiliy Manchaary, a defender of the people and a popular riot maker. In Yakut literature, there are many instances of the authors turning to the image of this character in various poetic and prose genres. I. Gogolev made a first attempt to recreate the life of this legendary character in the form of a novel.

I. Gogolev's novel stands out among others with its features of the historical and biographical as well as the historical and philosophical genre; the boundary between them is hardly visible. Real events form the basis of the plot and it traces the life journey of Manchaary - from the day he was born to the last days of his life. The idea of being the chosen one runs through the entire plot of the novel.

The text of the novel is exceptionally poetical and filled with exquisite verses. Sounding somewhat like a poem written in prose form, the author gives a description of how the father is making a crib for his newborn son made from the holy tree of the aiyy people - the birch tree: "... building a crib is like building life", "Oh, pure birch-tree! Your heart is in a birch forest, it sings with joy and banishes all that is evil...".

Initially, the motif of childbirth itself in a typical peasant family was encompassed by a chain of symbolic images or symbols. Another symbolic image, which takes its roots from the poetics of legendary tales - is the bold eagle, which resembles a strong and independent nature of the main character. In explaining the meaning of his prophetic dream, the wise Akymallay foretells that "your son is of the bold eagle tribe".

Combined together, the realistic and mythological plane of the novel plot unfolds a story of Manchaary's childhood and how he developed as an individual. The implied context of the main character's name also contains symbolic features: the sharp-leafed grass manchaary symbolizes uncontrollable temper and bravery: "My son was born on a bed of sharp manchaary leaves and let him be just as brave!" (Gogolev, 2001, p.12).

The philosophical plane of the plot unfolds even further owing to the myths and legends and reminiscences from olonkho as well as numerous proverbs and sayings. In his childhood, Manchaary would listen closely to the olonkho stories about a mighty aiyy bobatyr (warrior), who saves many people from the forces of evil by battling them in all the three worlds - the Upper, the Middle and the Underworld. In the legend about a raven, the son of a demigod, who destroyed everything in his path, the author uses a metaphorical image of the main character to express his negative attitude towards massacre. In his opinion it is the heaviest sin of all.

Manchaary developed an early feeling of intolerance towards any form of oppression and humiliation in relation to human beings; this caused a conflict with Chocho-buy and this is how his roaming from one prison to another began. An arrogant and independent attitude, and a strong feeling of injustice push him towards desperate actions.

The micro-cosmos of the native alaas (place of living in Yakut culture) and the atmosphere of native nature played a key role in the formation of Manchaary's character. Already at a young age, Manchaary sang his first song, a poem about his native alaas. The mythical and poetical locus of the alaas serves as the geocultural center of the storyline. The eternal image of the tree of life, a majestic pine tree growing on the 
border of the alaas, is represented as a spiritual twin of the main character. In the darkest times of his life, Manchaary comes to this pine tree, finding compassion and understanding in it.

The surrounding world of nature planted an unbreakable feeling of love for his native land in the heart of the main character; this feeling accompanies him through his hardships in life full of losses and wanderings. Escaping from the places of imprisonment, each time he once again feels that he is an aiyy person, but only upon returning to his native land, as if regaining wings once more. In the minds of the people, Manchaary is remembered as a toiyuksut or an poet-improviser. Mythological characters are naturally inserted into the realistic storyline. Thus, the spirit of nature feels compassionate for the difficult fate of Manchaary; he came to this world with a peaceful mission to become the great toiyuksut "with a kind heart and noble thoughts". In the poetic style of traditional legends, the author shows the interrelations between Manchaary and his beloved women: it is the light of love that helped to preserve his humanistic self during his imprisonment and to continue believing in the purpose of life. The concept of a khomus held in the hands of a beloved woman is another symbol; it illuminates and guides the difficult journey of the main character through life filling it with brighter days.

The idea of a great destiny of the main character passes through the entire plot of the story. This is achieved through the dramatic and philosophical features of the main characters monologues and dialogues. This idea, which forms the basis of the author's concept, connects the beginning, endings and the epilogue and prologue of the novel.

In the epilogue, sitting in the gloomy prison cell, the menacing two-headed bird of death attempts to break the main character's desire to live. The love for freedom and the light of love helps Manchaary withstand in this uneven battle: "I was saved by the holy light of great love" (Gogolev, 2001, p.5).

The epilogue specifies Manchaary's love of freedom, whereas the prologue continues to ponder about the purpose of a person's life, freedom and happiness using mythological context. In the concluding chapters of the novel the main character explains his understanding of happiness and manages to prove his point in a philosophical dispute: "Though I have spent my life in a prison cell, in a struggling battle for life, in an exile, I am nevertheless an independent person. Therefore, I am happy". Manchaary believes that he managed to escape from three kinds of addictions: the temptation of power, wealth and envy and found inner strength to stand up first and to rise against cruelty and assault (Gogolev, 2001, p.348).

I have made a bold decision -

To rise bravely and perilously

Against the assault of those living in the Middle World.

As a result, in a combination of the mythological and the realistic and based on the traditional and poetic traditions, the authors unfolds the story of the legendary character of many myths and legends.

\section{Conclusion}

Thus, in its process of development at the turn of the 20th and 21st centuries, the Yakut novels attained features of traditional and epic traditions as well as olonkho traditions. The use of mythical and poetical structures allows expanding the genre and stylistic possibilities of modern prose. At the new stage of language art development, novels written by the most prominent prose writers contain a tradition of implementing historical, biographical, social and philosophical genres which originates from the creative writing of P.A. Oyunsky.

The philosophical and mythological motifs manifest themselves on different levels of the epic storyline: in the point of view of the author, in the special style, and in the moral and philosophical concept of the novel 
in general. New novel and viewpoint features are apparent in creative writings by V. Dalan, I. Gogolev and others. The folklore poetics as the style-forming source attains a new quality. Authors base their plotline on the inner mythical and syncretic structures, synthesizing myths and history, the real and the mythological; all this allows the writers to express the multi-dimensional nature of the world and the infiniteness of what is true in life.

\section{References}

Borisov, A. A. (1998). Tygyn - a legendary person and a symbol. llin 2-3, 33.

Dalan, V. S. (1994). Tygyn Darkhan. Yakutsk: Bichik.

Gogolev, I. M. (1977). Khara kytalyk. A Black Crane, Book 1. Yakutsk: Knizhnoye Izdatelstvo Press.

Gogolev, I. M. (1993). leyehsiti keletii. The Goddess of Mercy. Yakutsk: Knizhnoye Izdatelstvo Press.

Gogolev, I. M. (2001). Manchaary. Yakutsk: Bichik Press.

Gumilyov, L. N. (1989). Ethnogenesis and the biosphere of the Earth, $2^{\text {nd }}$ edition. Leningrad: Leningrad State University (LSU) Press.

Oyunsky, P. A. (1995). Kudangsa the Great). A legend. Yakutsk: Sakhapoligrafizdat Press.

Pukhov, I. V. (1980). From folklore to literature. Yakutsk: Knizhnoye Izdatelstvo Press.

Volkov, I. F. (1995). The Theory of Literature. Moscow: Prosvesheniye, Vlados Press. 